\title{
Online cetacean habitat modeling system for the US east coast and Gulf of Mexico
}

\author{
Benjamin D. Best ${ }^{1,2, *}$, Patrick N. Halpin ${ }^{1,2}$, Andrew J. Read ${ }^{1}$, Ei Fujioka ${ }^{2}$, \\ Caroline P. Good ${ }^{1}$, Erin A. LaBrecque ${ }^{1,2}$, Robert S. Schick ${ }^{2}$, Jason J. Roberts ${ }^{2}$, Lucie \\ J. Hazen², Song S. Qian ${ }^{3}$, Debra L. Palka4 ${ }^{4}$ Lance P. Garrison ${ }^{5}$, William A. McLellan \\ ${ }^{1}$ Duke University Marine Laboratory, Beaufort, North Carolina 28516, USA \\ ${ }^{2}$ Nicholas School of the Environment and Earth Sciences, Duke University, Durham, North Carolina 27708-0328, USA \\ ${ }^{3}$ Department of Environmental Sciences, University of Toledo, Toledo, Ohio 43606, USA \\ ${ }^{4}$ Protected Species Branch, Northeast Fisheries Science Center, Woods Hole, Massachusetts 02543, USA \\ ${ }^{5}$ Protected Resources and Biodiversity, Southeast Fisheries Science Center, Miami, Florida 33149, USA \\ ${ }^{6}$ University of North Carolina Wilmington, Biology \& Marine Biology, Wilmington, North Carolina 28403, USA
}

\begin{abstract}
We describe the development of a comprehensive set of marine mammal habitat models for the US east coast and Gulf of Mexico and their delivery through an online mapping portal. Drawing from datasets in the online OBIS-SEAMAP geo-database, we integrated surveys conducted by ship $(n=36)$ and aircraft $(n=16)$, weighting a generalized additive model (GAM) by minutes surveyed within space-time grid cells to harmonize effort between the 2 survey platforms. For each of 16 cetacean species guilds, we predicted the probability of occurrence from static environmental variables (water depth, distance to shore, distance to continental shelf break) and time-varying conditions (monthly sea surface temperature). To generate maps of presence versus absence, receiver operator characteristic (ROC) curves were used to define the optimal threshold that minimizes false positive and false negative error rates. We integrated model outputs, including tables (species in guilds, input surveys) and plots (fit of environmental variables, ROC curve), into an online spatial decision support system (SDSS), allowing for easy navigation of models by taxon, region, season, and data provider. Users can define regions of interest and extract statistical summaries of the model for that region. The SDSS also displays density models from other providers and regions (e.g. Pacific Ocean). This versatile, easy-to-use online system enables the application of these habitat models to real-world conservation and management issues. Finally, we discuss the ecological relevance of these model outputs and identify key data gaps across species, regions, and seasons.
\end{abstract}

KEY WORDS: Species distribution model $\cdot$ Habitat $\cdot$ Cetacea $\cdot$ Generalized additive model Spatial decision support system · Atlantic Ocean · Gulf of Mexico

\section{INTRODUCTION}

The ability to conserve and manage cetacean populations fundamentally depends upon describing their distribution in time and space. Human activities pose multiple threats to cetacean populations, such as fisheries bycatch and food depredation (Read
2008, Moore et al. 2009), ship strikes (Laist et al. 2001), anthropogenic noise (Weilgart 2007), contaminants (O'Shea \& Brownell 1994, Aguilar et al. 2002), and global warming (Learmonth et al. 2006, Alter et al. 2010). Relocating potentially harmful human activities away from known cetacean distributions is often the best way to minimize these threats (Dolman 
et al. 2009). Habitat models which relate past observations to the environment provide a predictive surface against which these management decisions can be made (Redfern et al. 2006). The ability for species distribution models to inform conservation management of cetaceans is a major thrust and application of the present paper.

Our goal was to develop a data management, statistical modeling, and decision support system describing the habitat use of marine mammals along the US east coast and in the Gulf of Mexico. The system uses data on the distribution of marine mammals generated by dedicated surveys contained in the publicly available online OBIS-SEAMAP marine data archive (Halpin et al. 2009). As part of a larger Ocean Biogeographic Information System (OBIS), the Spatial Ecological Analysis of Megavertebrate Populations (SEAMAP) component focuses on marine mammal, seabird, and sea turtle collections. OBIS further propagates its observational data to the Global Biodiversity Information Facility (GBIF), which is inclusive of terrestrial biota. We aimed to use the greatest number of scientifically collected, publicly available datasets from both boat and plane survey platforms for modeling.

The literature on species distribution modeling is vast and has been thoroughly reviewed elsewhere (Elith \& Leathwick 2009, Cushman \& Huettmann 2010, Franklin \& Miller 2010). In ecological terms, the habitat modeled here is presumed to be the realized niche or the 'n-dimensional hypervolume' (Hutchinson 1957). Interspecies competition and prey were not explicitly modeled, but expected to interplay with physiological constraints to produce this realized niche. Rather than a mechanistic model befitting a purely ecological understanding of the species distribution (Guisan \& Zimmermann 2000), these models provide a statistical correspondence to the environment intended for predictions relevant to marine spatial planning.

Species distribution models based on the underlying environment can predict outputs ranging from probability of occurrence estimated from opportunistic presence-only observations, such as with Maxent (Phillips \& Dudik 2008), to full-fledged heterogeneous maps of absolute abundance estimated from line transect surveys, such as with distance sampling and density surface modeling methodologies (Thomas et al. 2010). Presence-only models require only observations and associated environmental data. In order to calculate density for classical line transect surveys, additional parameters must be estimated, such as the probability of encounter on the trackline and the effective strip width (Buckland et al. 2001). These parameters often vary by species, region, platform, observing conditions, and even observer. Subsequently combining results from various platforms for the same species and region presents an unsolved problem with the density approach. On the other hand, presence-only models do not account for where the vessel visited and found no species. Instead, species habitat is differentiated by either generating random pseudo-absence data points or drawing from the entire range of environmental background within the study area (Phillips et al. 2009, Ready et al. 2010). Alternatively, where survey effort is recorded, presence and absences can be explicitly modeled from transect segments. In cases of poor sampling frequency or rare/cryptic species, as is common with marine fauna, this transect approach typically yields a vast majority of segments classified as absences. This well known statistical issue of 0 inflation makes model fitting problematic.

To resolve the issue of including survey effort absences without 0 inflation, we used a generalized additive modeling (GAM) framework with a grid over the study area, replicated by months surveyed. We segmented monthly survey tracklines by grid cells to calculate the minutes surveyed per space-time cell as our measure of survey effort. Only grid cells with survey effort were included in the fitting of the GAM. We modeled probability of presence as the response and applied minutes surveyed as the weight, similar to a sightings per unit effort (SPUE) approach. The North Atlantic Right Whale Consortium calculated effort for SPUE in $\mathrm{km}$ of trackline to pool survey platforms (Pittman et al. 2006, Fonnesbeck et al. 2008, Pershing et al. 2009, Pittman \& Costa 2010). Elsewhere, units of time have been used (Tetley et al. 2008).

Previous studies have attempted to elucidate relationships between marine mammal communities and their habitats within the US Exclusive Economic Zone (EEZ), which extends 200 nautical miles offshore (Reilly \& Fiedler 1994, Davis et al. 1998, Hamazaki 2002, Mullin \& Fulling 2004, Waring et al. 2009). Despite these preliminary studies, the relationship between many marine mammals and their habitats is still poorly understood and insufficient to predict their presence in particular areas.

Delivery of these models to end users engaged in marine spatial planning is best accomplished with an interactive mapping interface which enables indepth examination of model surfaces by species, region, and season. The ability to extract model output summaries for user-defined coordinates further enables the interface to readily evaluate environ- 
mental impacts for a proposed area of human activity. Ancillary information, such as input survey tracks and marine mammal sightings, along with descriptive model outputs are beneficial for a review of modeling details. Hence, all available model data and supporting information specific to an area of interest can be quickly tabulated, mapped, and incorporated into the marine spatial planning process.

Here we describe a GAM modeling framework which allows for effort-corrected incorporation of datasets from multiple platforms, the resulting ecological insights from the models, and the spatial decision support system to readily view them for practical management applications.

\section{MATERIALS AND METHODS}

The development of the marine mammal habitat models followed 5 general steps: (1) gathering sightings of marine mammals and associated survey effort; (2) sampling date-synchronous environmental data; (3) fitting multivariate statistical models to the data; (4) predicting habitat from the models across a seascape with time-specific environmental conditions; and (5) presentation of results within a spatial decision support system (SDSS).

\section{Marine mammal surveys}

Our study area encompasses the entire US EEZ along the Atlantic east coast and Gulf of Mexico, which corresponds to the strata for which the surveys were designed. We delineated 3 regions to allow for a hierarchical modeling approach: (1) Gulf of Mexico (GoM); (2) Southeast Atlantic US coast (SE); and (3) Northeast Atlantic US coast ( $\mathrm{NE}_{\text {; }}$ Fig. 1 ). These 3 regions were delineated based on the biogeography of the area (Ekman 1953, Angel 1979, MacLeod 2000). The boundary between NE and SE corresponds to the separation between temperate and sub-tropical ecosystems at the point at which the Gulf Stream veers offshore of Cape Hatteras, North Carolina (Fig. 1). We also combined the SE and $\mathrm{NE}$ into an east coast region (East) to test for a more robust model that in- cludes more sightings based on model selection parameters (e.g. Akaike's information criterion, unbiased risk estimator, area under the receiver operating curve, and deviance explained). We also explored the effects of combining sightings from the entire study area (i.e. GoM and East) into a single model. We used the $5 \mathrm{~m}$ contour as the near-shore boundary and the EEZ as the offshore boundary, with some extensions to include US Navy operating areas.

Within the 3 regions, we searched the online OBISSEAMAP marine archive (http://seamap.env.duke. edu) for marine mammal survey datasets (Halpin et al. 2009). We restricted our search to aerial and shipboard line-transect surveys of marine mammals, conducted primarily by NOAA researchers engaged in stock assessment surveys. These sightings were augmented by similar surveys conducted by academic researchers, using essentially the same protocols. All of these datasets quantified on-effort observation (i.e. survey tracks) and were collected by expert, professional observers; we did not use any opportunistic surveys. We restricted our search for marine mammal surveys to years after 1985, when the earliest sea surface temperature satellite records became available

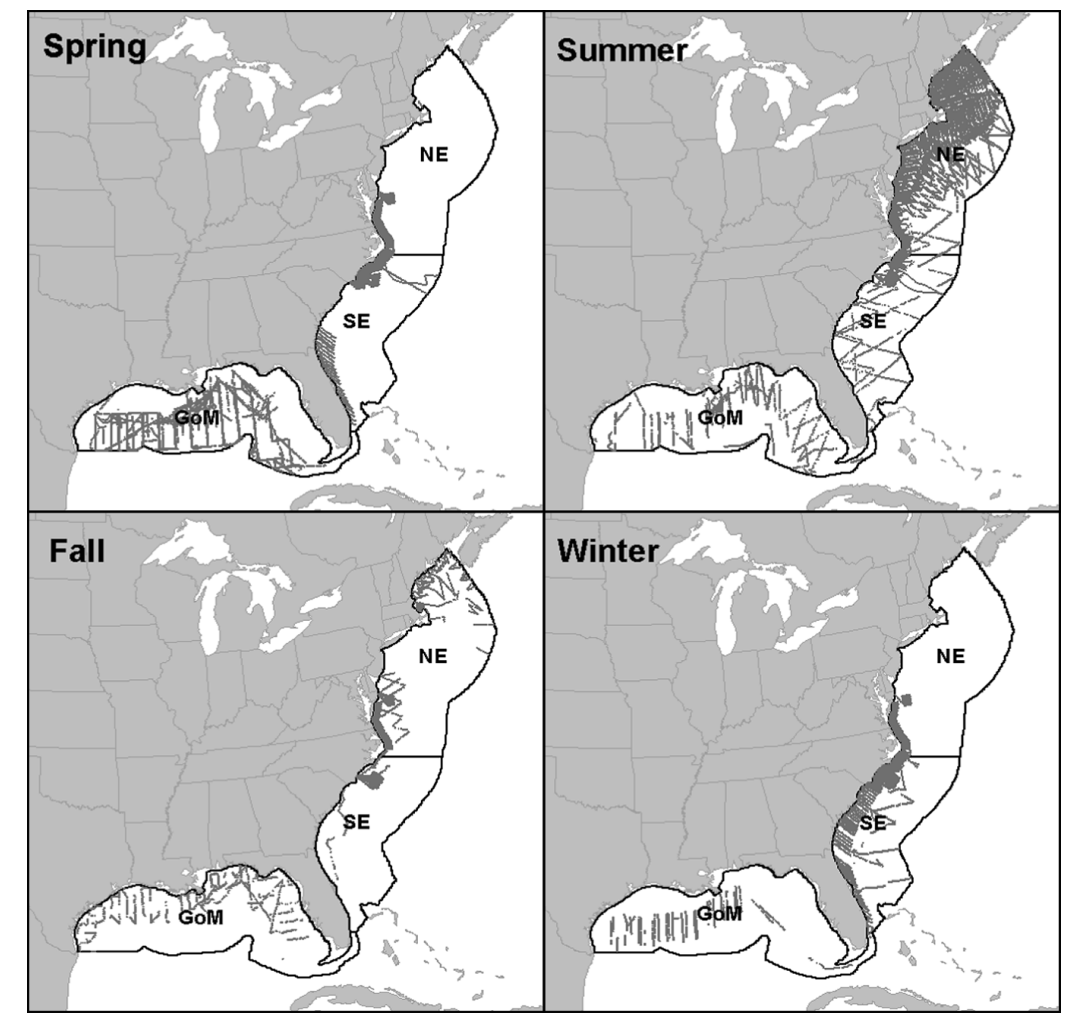

Fig. 1. Survey effort pooled across datasets by season within study regions: Gulf of Mexico (GoM), Southeast (SE) and Northeast (NE) Atlantic US coasts. The NE and SE regions combined make up the US east coast region (East). The map projection is North America Albers Equal Area 
through the $4 \mathrm{~km}$ Advanced Very High Resolution Radiometer (AVHRR) Pathfinder Project (Kilpatrick et al. 2001).

Thus, the data we used to predict habitat suitability for marine mammals came from government agencies and academic institutions that contributed to OBIS-SEAMAP. The 2 primary data sources were marine mammal surveys conducted by the Northeast Fisheries Science Center (NEFSC) in Woods Hole, Massachusetts, and the Southeast Fisheries Science Center (SEFSC) in Miami, Florida. The surveys were conducted from 1991 to 2007 and covered the entire Atlantic US east coast and Gulf of Mexico. These are the most extensive marine mammal survey data sets available within the US east coast EEZ. All scientific surveys with standardized effort in the US east coast and Gulf of Mexico were pooled for analysis from OBIS-SEAMAP for a total of 11006 unique marine mammal sightings between 1991 and 2006 across 52 datasets, of which 36 were by ship and 16 by aircraft (Table 1).

Despite this compilation of data sets, sample sizes were inadequate to build separate habitat suitability models for each species, so we grouped species at various taxonomic levels to create species 'guilds.' Each guild was established using information on species distributions, interactions, and other expert knowledge. Each guild was compared to environmental ordination results for validation of its members (see Schick et al. 2011 for full details). The final cetacean guilds we used in models of habitat suitability include: baleen whale, humpback whale, right whale, beaked whale, sperm whale, Kogia spp., killer whale, pilot whale, Lagenorhynchus spp., common dolphin, spinner dolphin, striped dolphin, pantropical spotted dolphin, Atlantic spotted dolphin, bottlenose dolphin, and harbor porpoise (Table 2).

\section{Environmental data}

For the $10 \mathrm{~km}^{2}$ sampling grid across the study area, edge cells less than half the full size were removed. The centroids of these cells were then used to sample the underlying environmental data. The environmental data layers we used to construct the habitat models are a combination of static, dynamic, and derived variables, all of which have been shown to be useful predictor variables for marine mammal habitats (Redfern et al. 2006).

For water depth, the General Bathymetric Chart of the Oceans (GEBCO; http://gebco.net) provides a 1 min global bathymetric surface. The $200 \mathrm{~m}$ contour from this grid is used for deriving distance from the continental shelf with the ArcGIS function EucDistance. The final static variable, distance from shore, is taken as the Euclidean distance from the NOAA Global Self-consistent, Hierarchical, High-resolution Shoreline Database (GSHHS, Wessel \& Smith 1996; http://ngdc.noaa.gov/mgg/shorelines/gshhs.html). All map layers were converted to the North American Albers Equal Area Conic projection to minimize map distortion and maximize the accuracy of distance calculations. Depth and distance from shore were log-transformed in the final model fitting to normalize the data.

Beyond sea surface temperature (SST), we wished to include chlorophyll a concentration and sea surface height, but in keeping with our desire to include as many datasets as possible for increased sample size, we limited our dynamic environmental data to SST, available since 1985 with AVHRR Pathfinder SST version 5 (http://pathfinder.nodc.noaa.gov). By comparison, chlorophyll is only consistently available through Sea-viewing Wide Field-of-view Sensor (SeaWiFS; http://oceancolor.gsfc.nasa.gov) since 1997, and sea surface height through the French project Archiving, Validation and Interpretation of Oceanographic Satellites (AVISO; www.aviso. oceanobs.com) since 1992. Use of chlorophyll or sea surface height would, therefore, have necessitated exclusion of surveys prior to 1997 and 1992, respectively. In order to minimize absence of SST caused by obscuring ephemeral clouds common in the shorterterm averaged products (i.e. daily and $8 \mathrm{~d}$ ), we used the monthly nighttime SST product. Much of the data processing has been handled through the use of automated scripts, custom GIS tools (Roberts et al. 2010), and geospatial web services which have been described elsewhere (Best et al. 2007).

Models were divided by the 4 seasons: winter (December to February), spring (March to May), summer (June to August), and fall (September to November). For the eastern regions (NE and SE), inclusion of latitude as a model predictor allowed fitting of known species range shifts. Marine mammal survey effort was not evenly distributed across seasons in the East and GoM regions (Fig. 1). Data analysis and model selection were often limited to the summer season due to data limitations.

\section{Modeling framework}

A table of data containing the absence or presence response within the given space-time cell 
Table 1. Survey datasets identified by provider, name, type of platform, begin/end date (given as yr-mo-d), and number of marine mammal sightings (N). DU: Dalhousie University, DUML: Duke University Marine Lab, NEFSC: Northeast Fisheries Science Center, SEFSC: Southeast Fisheries Center, UNCW: University of North Carolina Wilmington, YoNAH: Years of the North Atlantic Humpback Whale consortium. USWTR: undersea warfare training

\begin{tabular}{|c|c|c|c|c|c|}
\hline Provider & Name & Platform & Begin & End & $\mathrm{N}$ \\
\hline DU & Sargasso cruise - sperm whale sightings & Boat & 2004-05-06 & 2004-06-15 & 11 \\
\hline \multirow[t]{3}{*}{ DUML } & Hatteras eddy cruise 2004 & Boat & 2004-08-15 & 2004-08-19 & 20 \\
\hline & Summer 2004 and winter 2005 Cape Hatteras & Boat & 2004-08-04 & 2005-02-02 & 70 \\
\hline & Vessel-based surveys for proposed Onslow Bay USWTR site & Boat & 2007-06-07 & $2007-11-20$ & 23 \\
\hline \multirow[t]{17}{*}{ NEFSC } & Aerial circle-back abundance survey 2004 & Plane & 2004-06-13 & 2004-07-12 & 287 \\
\hline & Aerial survey, experimental 2002 & Plane & $2002-07-20$ & $2002-08-10$ & 332 \\
\hline & Aerial survey, summer 1995 & Plane & 1995-08-05 & 1995-09-17 & 304 \\
\hline & Aerial survey, summer 1998 & Plane & 1998-07-19 & 1998-08-20 & 422 \\
\hline & Harbor porpoise survey 1991 & Boat & 1991-07-24 & 1991-08-27 & 770 \\
\hline & Harbor porpoise survey 1992 & Boat & 1992-07-31 & 1992-09-05 & 1238 \\
\hline & Joint deepwater systematics and marine mammal survey & Boat & 2002-07-18 & 2002-08-01 & 105 \\
\hline & Marine mammal abundance survey, leg 1 & Boat & $1995-07-10$ & 1995-08-02 & 433 \\
\hline & Marine mammal abundance survey, leg 2 & Boat & 1995-08-09 & 1995-09-05 & 153 \\
\hline & Marine mammal survey 1991-10 & Boat & 1991-10-13 & $1991-10-24$ & 80 \\
\hline & Marine mammal survey 1992 & Boat & 1999-07-29 & $1999-08-27$ & 1021 \\
\hline & Marine mammal survey 1997 & Boat & 1997-08-23 & 1997-09-04 & 60 \\
\hline & Marine mammal survey 1998, part 1 & Boat & 1998-07-08 & 1998-08-03 & 492 \\
\hline & Marine mammal survey 1998, part 2 & Boat & 1998-08-09 & 1998-08-31 & 309 \\
\hline & Mid-Atlantic marine mammal abundance survey 2004 & Boat & 2004-06-24 & 2004-08-03 & 522 \\
\hline & Summer marine mammal survey 1995, part I & Boat & 1995-07-11 & 1995-08-01 & 150 \\
\hline & Summer marine mammal survey 1995, part II & Boat & $1995-08-07$ & 1995-09-04 & 1401 \\
\hline \multirow[t]{23}{*}{ SEFSC } & Atlantic cetacean survey 1992 & Boat & 1992-01-04 & 1992-02-10 & 77 \\
\hline & Atlantic cetacean survey 1999 & Boat & 1999-08-09 & 1999-09-25 & 236 \\
\hline & Atlantic surveys, 1998 & Boat & 1998-07-09 & 1998-08-20 & 287 \\
\hline & Caribbean survey 2000 & Boat & $2000-02-17$ & $2000-04-02$ & 196 \\
\hline & Eastern Gulf of Mexico marine mammal survey 1994 & Boat & 1994-08-16 & 1994-09-08 & 305 \\
\hline & Gulf of Mexico marine mammal survey 1992 & Boat & $1992-04-22$ & 1992-06-07 & 270 \\
\hline & Gulf of Mexico marine mammal survey 1993, summer & Boat & 1993-05-04 & $1993-06-15$ & 271 \\
\hline & Gulf of Mexico marine mammal survey 1993, winter & Boat & 1993-01-06 & 1993-02-12 & 45 \\
\hline & Gulf of Mexico marine mammal survey 1994 & Boat & 1994-04-16 & 1994-06-09 & 286 \\
\hline & Gulf of Mexico shelf 2001 & Boat & 2001-08-31 & 2001-09-28 & 225 \\
\hline & Mid-Atlantic Tursiops surveys 1995 (1) & Plane & 1995-07-13 & $1995-07-23$ & 47 \\
\hline & Mid-Atlantic Tursiops surveys 1995 (3) & Plane & 1995-07-31 & 1995-08-13 & 46 \\
\hline & Mid-Mid Atlantic Tursiops surveys 1995 (2) & Plane & $1995-07-24$ & 1995-07-31 & 50 \\
\hline & Northern Gulf of Mexico cetacean survey 1998 & Boat & 1998-09-07 & $1998-09-24$ & 42 \\
\hline & Northern Gulf of Mexico marine mammal survey 2000 & Boat & $2000-09-07$ & 2000-10-01 & 84 \\
\hline & Oceanic Gulf of Mexico cetacean survey 1996 & Boat & 1996-04-17 & 1996-06-08 & 536 \\
\hline & Oceanic Gulf of Mexico cetacean survey 1997 & Boat & $1997-04-17$ & 1997-06-09 & 268 \\
\hline & Oceanic Gulf of Mexico cetacean survey 1999 & Boat & 1999-04-23 & 1999-06-01 & 217 \\
\hline & Oceanic Gulf of Mexico cetacean survey 2000 & Boat & $2000-04-20$ & $2000-05-29$ & 198 \\
\hline & Oceanic Gulf of Mexico cetacean survey 2001 & Boat & 2001-04-18 & 2001-05-30 & 181 \\
\hline & Southeast cetacean aerial survey 1992 & Plane & 1992-01-20 & 1992-03-02 & 263 \\
\hline & Southeast cetacean aerial survey 1995 & Plane & $1995-01-27$ & 1995-03-06 & 176 \\
\hline & Gomex sperm whale survey 2000 & Boat & $2000-06-28$ & $2000-07-26$ & 278 \\
\hline \multirow[t]{7}{*}{ UNCW } & 2008 Right whale aerial surveys & Plane & 2008-02-02 & 2008-06-14 & 565 \\
\hline & Aerial survey $98-99$ & Plane & 1998-09-14 & $1999-10-30$ & 177 \\
\hline & Aerial surveys for proposed Onslow Bay USWTR site, left & Plane & $2007-06-26$ & $2007-12-11$ & 10 \\
\hline & Aerial Surveys for proposed Onslow Bay USWTR site, right & Plane & $2007-06-26$ & $2007-12-11$ & 16 \\
\hline & Marine mammal aerial surveys 2006-2007 & Plane & 2006-12-05 & $2007-05-02$ & 929 \\
\hline & Marine mammal sightings, southeastern US 2001 & Plane & 2001-02-06 & 2001-03-02 & 402 \\
\hline & Right whale aerial survey 05-06 & Plane & $2005-10-27$ & $2006-04-20$ & 690 \\
\hline YoNAH & Years of the North Atlantic Humpback Whale & Boat & 1992-01-15 & 1993-12-08 & 4215 \\
\hline
\end{tabular}


Table 2. Taxonomic members of cetacean guilds and IUCN Red List status of species (www.iucnredlist.org). DD: Data Deficient, LC: Least Concern, VU: Vulnerable, EN: Endangered

\begin{tabular}{|c|c|c|c|}
\hline Guild & Scientific name & Common name & Status \\
\hline \multirow[t]{6}{*}{ Baleen whale } & Balaenoptera spp. & Baleen whales & \\
\hline & Balaenoptera acutorostrata & Minke whale & LC \\
\hline & Balaenoptera borealis & Sei whale & EN \\
\hline & Balaenoptera edeni & Bryde's whale & $\mathrm{DD}$ \\
\hline & Balaenoptera musculus & Blue whale & $\mathrm{EN}$ \\
\hline & Balaenoptera physalus & Fin whale & EN \\
\hline Humpback whale & Megaptera novaeangliae & Humpback whale & $\mathrm{LC}$ \\
\hline Right whale & Eubalaena glacialis & North Atlantic right whale & EN \\
\hline \multirow[t]{10}{*}{ Beaked whale } & Berardius bairdii & Baird's beaked whale & $\mathrm{DD}$ \\
\hline & Hyperoodon ampullatus & North Atlantic bottlenose whale & $\mathrm{LC}$ \\
\hline & Mesoplodon spp. & Beaked whales & \\
\hline & Mesoplodon bidens & Sowerby's beaked whale & DD \\
\hline & Mesoplodon densirostris & Blainville's beaked whale & DD \\
\hline & Mesoplodon europaeus & Gervais' beaked whale & $\mathrm{DD}$ \\
\hline & Mesoplodon mirus & True's beaked whale & $\mathrm{DD}$ \\
\hline & Ziphiidae & Beaked whales & \\
\hline & Ziphius spp. & Goose-beaked whales & \\
\hline & Ziphius cavirostris & Cuvier's beaked whale & $\mathrm{LC}$ \\
\hline Sperm whale & Physeter macrocephalus & Sperm whale & VU \\
\hline \multirow[t]{3}{*}{ Kogia spp. } & Kogia spp. & Kogia & \\
\hline & Kogia breviceps & Pygmy sperm whale & $\mathrm{DD}$ \\
\hline & Kogia sima & Dwarf sperm whale & $\mathrm{DD}$ \\
\hline \multirow[t]{4}{*}{ Killer whale } & Orcinus orca & Killer whale & $\mathrm{DD}$ \\
\hline & Feresa attenuata & Pygmy killer whale & DD \\
\hline & Peponocephala electra & Melon-headed whale & $\mathrm{LC}$ \\
\hline & Pseudorca crassidens & False killer whale & DD \\
\hline \multirow[t]{3}{*}{ Pilot whale } & Globicephala spp. & Pilot whales & \\
\hline & Globicephala macrorhynchus & Short-finned pilot whale & $\mathrm{DD}$ \\
\hline & Globicephala melas & Long-finned pilot whale & $\mathrm{DD}$ \\
\hline \multirow[t]{3}{*}{ Lagenorhynchus spp. } & Lagenorhynchus spp. & White-beaked dolphins & \\
\hline & Lagenorhynchus acutus & Atlantic white-sided dolphin & LC \\
\hline & Lagenorhynchus albirostris & White-beaked dolphin & $\mathrm{LC}$ \\
\hline \multirow[t]{2}{*}{ Common dolphin } & Delphinus spp. & Common dolphin & \\
\hline & Delphinus delphis & Common dolphin & $\mathrm{LC}$ \\
\hline \multirow[t]{2}{*}{ Spinner dolphin } & Stenella clymene & Short-snouted spinner dolphin & $\mathrm{DD}$ \\
\hline & Stenella longirostris & Spinner dolphin & $\mathrm{DD}$ \\
\hline Striped dolphin & Stenella coeruleoalba & Striped dolphin & LC \\
\hline Pantropical spotted dolphin & Stenella attenuata & Pantropical spotted dolphin & LC \\
\hline Atlantic spotted dolphin & Stenella frontalis & Atlantic spotted dolphin & $\mathrm{DD}$ \\
\hline Bottlenose dolphin & Tursiops truncatus & Bottlenose dolphin & LC \\
\hline Harbor porpoise & Phocoena phocoena & Harbor porpoise & $\mathrm{LC}$ \\
\hline
\end{tabular}

and the associated environmental data was used to fit a GAM using the mgcv package (Wood 2006) in the open-source R statistical platform (R Development Core Team 2008). We used a quasi-binomial distribution to model the binary response to allow for dispersion, i.e. many 0s or absences. Effort, applied as a GAM weight, was calculated as minutes spent observing within the given month divided by the area of the cell in $\mathrm{km}^{2}$. This weighting process allows datasets from both ship and aircraft to be utilized within the habitat modeling process, using time spent surveying as the common denominator.
A GAM allows for non-linear relationships, which can increase the predictive strength of the fit but also risks over-fitting the model and can introduce complexities not easily explained ecologically (Austin 2007). Therefore, we restricted this spline-fitting process to 5 knots, or inflection points, and imposed a slightly greater penalty to extra knots with a gamma term of 1.4 over the default of 1.2 (Wood 2006). A polynomial fit of 3 knots enables a parabolic response as would be expected to describe a preferred habitat peak decaying on either side. The extra 2 knots allow for dampened tails which can lessen extreme effects approaching the outer range of the environmental 
parameter. Model selection was conducted using a basis smoothing function which shrinks non-significant terms to 0 degrees of freedom, i.e. thin-plate splines with shrinkage. In practice, the R statistical modeling formulation is:

$$
\begin{aligned}
& \text { gam(presence } \sim \mathrm{s}\left(\log (\text { depth }), \mathrm{k}=5, \mathrm{bs}={ }^{\prime} \mathrm{ts}^{\prime}\right)+ \\
& \mathrm{s}\left(\mathrm{d} 2 \mathrm{shelf}, \mathrm{k}=5, \mathrm{bs}=\text { 'ts' }^{\prime}+\right. \\
& \mathrm{s}\left(\log (\mathrm{d} 2 \text { coast }), \mathrm{k}=5, \mathrm{bs}={ }^{\prime} \mathrm{ts} \text { ') }+\right. \\
& \mathrm{s}(\mathrm{sst}, \mathrm{k}=5, \mathrm{bs}=\text { 'ts'), } \\
& \text { family = quasibinomial }(\text { link }=\text { 'logit'), } \\
& \text { weights }=\text { effort, gamma }=1.4 \text { ) }
\end{aligned}
$$

The multivariate regression model, once fitted, was then used to predict across the seascape study area using representative seasonal values. SST values were applied based on the median month of the fitted season (e.g. July for the summer season June through August) in the year 2007, being the nearest full year of data available at the time of analysis. Surfaces of standard error were produced for each model prediction. We also generated a binary representation by applying a threshold on the probability of occurrence resulting in polygons of habitat, differentiated from non-habitat. Receiver operating characteristic (ROC) curves were used to define an optimal threshold (Fielding \& Bell 1997) which simultaneously minimized the false absence and false presence rates based on cross validation.

We examined each model output for accuracy based on existing knowledge of species distributions, and GAM outputs, such as deviance explained. We first eliminated from consideration any models developed with fewer than 10 sightings. Second, each model was compared with primary literature regarding the distribution of species and guilds. This allowed us to identify models with highly erroneous predicted species distributions. Third, we examined models where some portion of the distribution had an especially high standard error. Finally, we reviewed the GAM results for each model, investigating the relationship between species distribution and each individual environmental parameter. Our review process allowed us to reject model outputs that were statistically weak or erroneous.

\section{Spatial decision support system}

To facilitate use of model outputs by environmental planners and researchers, we developed a flexible, interactive online interface. This browser-based SDSS enables viewing and extraction of original survey effort, marine mammal sightings, and model results (http://seamap.env.duke.edu/prod/serdp/ serdp_map.php).

In the SDSS, the model outputs are structured in a hierarchy of guild, season, and region. A folder-like navigation menu helps users to find a model output of their interest with a backdrop of Google imagery (Fig. 2). Upon selection of a particular model output, the mean prediction surface map layer is made visible. Ancillary support information is included in the information tabs below the mapping pane. The model description tab provides basic information such as the amount of survey effort, species in the guild, contributing datasets, GAM terms plots showing response curves for each predictor, and ROC plot determining the cutoff value for the binary habitat. Contributing datasets are linked to the OBISSEAMAP dataset record with the full metadata and download links for effort and sightings. The options button allows for alternatively mapping the standard error or binary habitat surfaces.

Contributing sightings and survey effort for the specific model can be overlaid from the toolbar checkboxes. The SDSS is built on a database that stores all sighting and survey effort data used in the calculations. Individual sightings and effort tracks can be clicked to bring up a balloon of details.

Among the more powerful features of the SDSS are its spatial subsetting capabilities (Fig. 3). End users may be interested in obtaining model results for specific regions within the modeled areas. These regions can be defined with a variety of methods: dragging a bounding box, drawing a polygon, entering latitude and longitude coordinates of a polygon, or selecting from a pre-loaded polygon. Thirteen naval exercise areas are pre-loaded in the SDSS. Once the area is specified, sightings and tracks are spatially filtered. The statistics of the model output (minimum, maximum, mean) in that area are calculated and presented with a histogram of the probability of occurrence in the statistical summary tab below the map, giving the user fine-tuned supporting data for making planning decisions. Any customized map and calculated statistics can be saved and later restored with a unique identifier. This feature allows planners to easily share the same user-defined interactive map and summary statistics with others or simply use it as an archive for self-reference.

The SDSS also incorporates into its navigational menu 2 additional projects that estimated marine mammal densities based on NOAA surveys. In the first project, the NOAA Southwest Fisheries Science Center produced models (Forney et al. 2012) for the eastern tropical Pacific, California coastal ecosystem, 


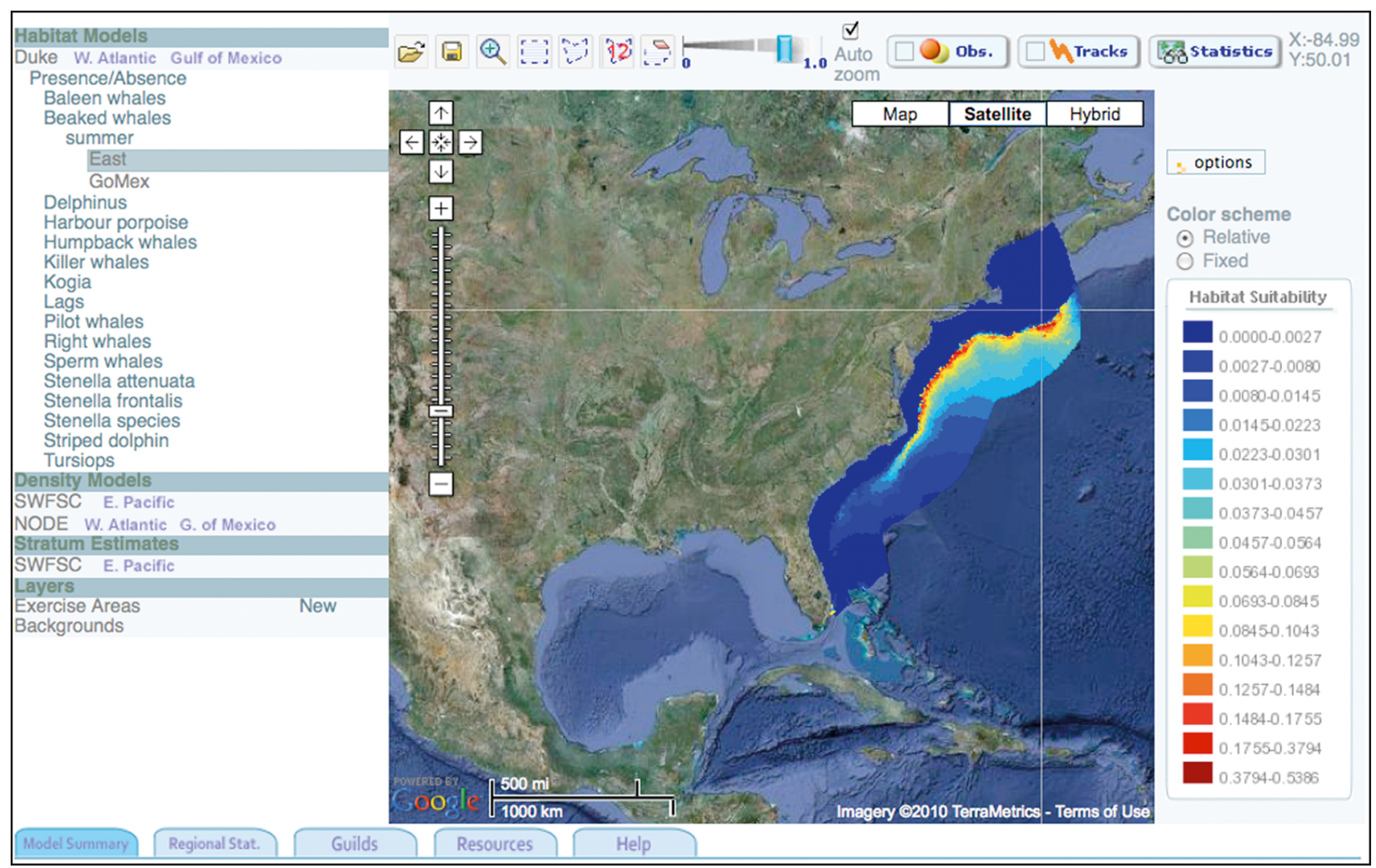

Fig. 2. Spatial decision support system (SDSS) interface showing predicted mean probability of occurrence for the summer beaked whales in the East region. Models can be selected by guild, season, and region in the navigation pane to the left, and displayed in the Google Map-based central pane with legend to the right. The 'options' button in the upper right allows for selection of mean prediction, standard error, or binary surfaces

and Hawaii. In the second project, the Navy operational area density estimates (NODEs) were generated by GeoMarine for the Gulf of Mexico (DON 2007a) and US Atlantic coast (DON 2007b,c). These density estimates had more stringent data input requirements to account for detectability parameters. Where available, density is preferred. Otherwise probability of occurrence is still helpful for informing the distribution. All of the features described above (polygon drawing, filtering, statistics with histograms) can be applied to these additional project model results in the same manner. For spatial subsets, instead of summarizing habitat, density is reported, allowing for estimated abundance of the specified area.

\section{RESULTS}

A total of 33 models passed the aforementioned criteria, with a maximum deviance explained of $62.3 \%$ (for humpback whales in the East during fall) and minimum of $6.6 \%$ (for Kogia spp. in the GoM for summer; Table 3). Ratios of presence to absence space-time cells ranged from 0.2 to $23.1 \%$. The diagnostic plots of variable response and mapped surfaces (mean, standard error, and binary) are too numerous to report in this article, but can be found online in our SDSS for all models.

\section{Seasonal data limitations}

The majority of survey effort occurred in the summer $(260 \mathrm{~h})$ and spring $(220 \mathrm{~h})$ versus fall $(69 \mathrm{~h})$ and winter $(73 \mathrm{~h})$. For winter, only the bottlenose dolphin guild had at least 100 sightings, and 9 of the 16 guilds had fewer than 10 sightings. Fall had 4 guilds (humpback whale, harbor porpoise, Atlantic spotted dolphin, and bottlenose dolphin) with over 100 sightings, despite $4 \mathrm{~h}$ less survey effort than winter. The distribution of survey effort was also more widespread in the fall, likely capturing the broader migratory ranges of the animals. For summer, 11 of the 16 guilds had sightings in excess of 100, while only 4 guilds met the same criteria for spring. 


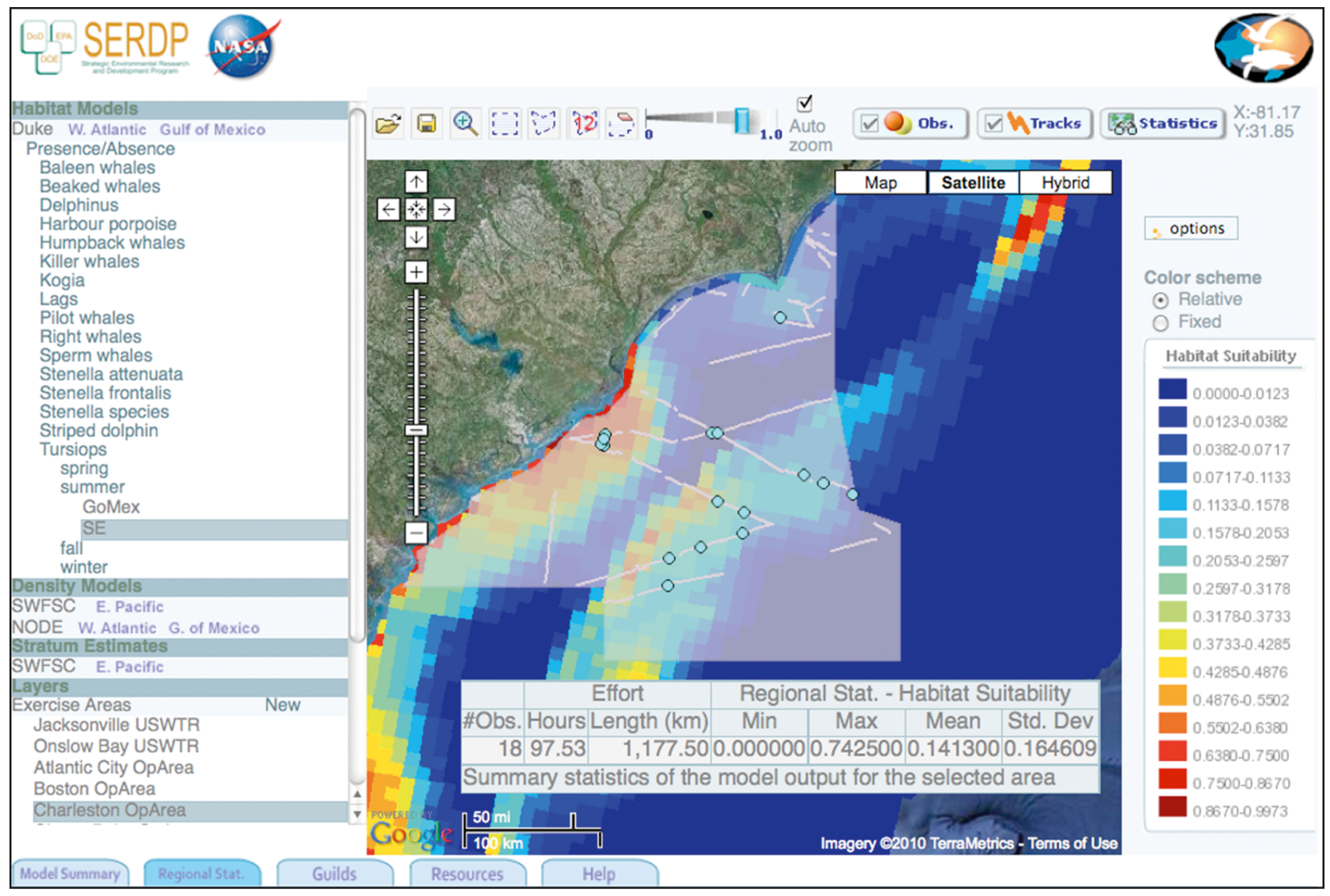

Fig. 3. Spatial subsetting of model results is enabled with polygon drawing tools or selection from pre-loaded US Navy training areas. Here, habitat for bottlenose dolphin Tursiops truncatus in summer for the Southeast (SE) region is displayed behind the selected Navy Charleston operation area. Summary statistics in the overlaid box for the subsetted polygon are based on sightings (turquoise circles), survey tracks (light gray lines), and model results (colored surface). Histograms of the region-specific model results and cumulative area (not pictured) are displayed below the 'Regional Statistics' tab. The map view such as the one shown here can be opened (folder icon) or saved (disk icon) from the toolbar using a generated identifier, making it easily redisplayable

Species guilds with the lowest number of sightings across all seasons were either rare or cryptic: killer whale $(\mathrm{n}=67)$, right whale $(\mathrm{n}=77)$, spinner dolphin $(\mathrm{n}=124)$, striped dolphin $(\mathrm{n}=195)$, Kogia spp. $(\mathrm{n}=$ $205)$, and beaked whale $(\mathrm{n}=251)$. Beaked whales are some of the most cryptic and rare species, hence the guild includes 10 beaked whale species (Table 2). Since sightings were aggregated to a binomial response (present or absent) for a given cell in time (i.e. monthly) and multiple sightings could occur for the same cell and month, the number of space-time cells with species present (Table 3) is usually lower than the total number of sightings.

\section{Gulf of Mexico}

A total of $65104.5 \mathrm{~km}(280.8 \mathrm{~d})$ of survey tracks were available for model building in the GoM, all of which were from ship-based surveys. Nine guilds were modeled for this region: beaked whale, sperm whale, killer whale, Kogia spp., spinner dolphin, pantropical spotted dolphin, Atlantic spotted dolphin, striped dolphin, and bottlenose dolphin. Models for each guild successfully reached a model fit, i.e. 'converged,' in the summer season except for striped dolphin. Due to the shortage of data available, no models converged for the winter season, and only a few models during the fall and spring seasons. Even if a model converges, it should be evaluated for reasonableness against previously established habitat predictors from the literature and expert opinion.

The Atlantic spotted dolphin occurs primarily from the continental shelf waters (10-200 m deep) to the slope waters $(<500 \mathrm{~m}$ deep $)$ in the Gulf of Mexico (Fulling et al. 2003, Mullin \& Fulling 2004), and has been seen in the Gulf of Mexico in all seasons (Waring et al. 2009). The fall pantropical spotted dolphin model 
Table 3. Deviance explained (Dev Expl), number of space-time cells present and absent in model fit for final models in Gulf of Mexico (GoM) and Atlantic US east coast (East) by guild, region, and season. Models for harbor porpoise and bottlenose dolphin are further split into Northeast (NE) and Southeast (SE) US coasts. The ratio of space-time cells present over absent indicates the degree of overdispersion, or 0-inflation, which challenges the model fitting

\begin{tabular}{|c|c|c|c|c|c|c|}
\hline Guild & Region & Season & Dev Expl (\%) & Present & Absent & Ratio $(\%)$ \\
\hline \multirow[t]{2}{*}{ Baleen whale } & \multirow[t]{2}{*}{ East } & Fall & 36.6 & 47 & 1817 & 2.59 \\
\hline & & Summer & 26.6 & 372 & 8706 & 4.27 \\
\hline \multirow[t]{2}{*}{ Beaked whale } & East & Summer & 28.0 & 121 & 8957 & 1.35 \\
\hline & GoM & Summer & 37.1 & 13 & 1391 & 0.93 \\
\hline Common dolphin & East & Summer & 21.3 & 187 & 8891 & 2.10 \\
\hline \multirow[t]{2}{*}{ Harbor porpoise } & \multirow[t]{2}{*}{$\mathrm{NE}$} & Fall & 59.9 & 46 & 1138 & 4.04 \\
\hline & & Summer & 50.2 & 396 & 7298 & 5.43 \\
\hline \multirow[t]{3}{*}{ Humpback whale } & \multirow[t]{3}{*}{ East } & Fall & 62.3 & 27 & 1837 & 1.47 \\
\hline & & Summer & 41.7 & 153 & 8925 & 1.71 \\
\hline & & Winter & 47.9 & 11 & 3891 & 0.28 \\
\hline Killer whale & GoM & Summer & 9.7 & 14 & 1390 & 1.01 \\
\hline Kogia spp. & GoM & Summer & 6.6 & 29 & 1375 & 2.11 \\
\hline Lagenorhynchus spp. & East & Summer & 31.3 & 151 & 8927 & 1.69 \\
\hline Pilot whale & East & Winter & 30.7 & 7 & 3895 & 0.18 \\
\hline Right whale & East & Summer & 32.3 & 17 & 9061 & 0.19 \\
\hline \multirow[t]{3}{*}{ Sperm whale } & \multirow[t]{2}{*}{ East } & Fall & 54.2 & 7 & 1857 & 0.38 \\
\hline & & Summer & 28.9 & 224 & 8854 & 2.53 \\
\hline & GoM & Summer & 29.1 & 40 & 1364 & 2.93 \\
\hline \multirow[t]{2}{*}{ Pantropical spotted dolphin } & \multirow[t]{2}{*}{ GoM } & Spring & 9.8 & 342 & 4475 & 7.64 \\
\hline & & Summer & 16.9 & 71 & 1333 & 5.33 \\
\hline \multirow[t]{3}{*}{ Atlantic spotted dolphin } & \multirow[t]{3}{*}{ GoM } & Fall & 15.3 & 73 & 872 & 8.37 \\
\hline & & Spring & 37.0 & 43 & 4774 & 0.90 \\
\hline & & Summer & 41.4 & 69 & 1335 & 5.17 \\
\hline Spinner dolphin & GoM & Summer & 26.2 & 15 & 1389 & 1.08 \\
\hline \multirow[t]{2}{*}{ Striped dolphin } & East & Summer & 28.9 & 115 & 8963 & 1.28 \\
\hline & GoM & Spring & 8.4 & 44 & 4773 & 0.92 \\
\hline \multirow[t]{7}{*}{ Bottlenose dolphin } & \multirow[t]{2}{*}{ GoM } & Fall & 30.2 & 160 & 785 & 20.38 \\
\hline & & Summer & 24.0 & 102 & 1302 & 7.83 \\
\hline & \multirow[t]{2}{*}{$\mathrm{NE}$} & Fall & 21.5 & 41 & 1143 & 3.59 \\
\hline & & Spring & 30.7 & 204 & 883 & 23.10 \\
\hline & \multirow[t]{3}{*}{$\mathrm{SE}$} & Spring & 17.2 & 225 & 1561 & 14.41 \\
\hline & & Summer & 46.1 & 88 & 1296 & 6.79 \\
\hline & & Winter & 14.4 & 478 & 2580 & 18.53 \\
\hline
\end{tabular}

for the GoM shows the highest probability of suitable habitat along the entirety of the continental shelf within the model area. The GAM term plot of depth illustrates an affinity to shallower waters.

Sperm whales are present year round in the GoM (Hansen et al. 1996, Mullin \& Hoggard 2000, Waring et al. 2009). Ship-based and aerial surveys indicate that sperm whales are widely distributed only in waters deeper than $200 \mathrm{~m}$ in the northern Gulf of Mexico (Waring et al. 2009); however, they aggregate around the continental shelf break and canyon regions (Davis et al. 1998, Baumgartner et al. 2001, Jochens \& Biggs 2003). The summer sperm whale model for the GoM shows the probability of highest suitable habitat for sperm whales along the shelf break off the Mississippi delta, Desoto Canyon, and western Florida. The depth GAM plot indicates a negative response to shallow waters $(<1000 \mathrm{~m})$ and a positive response to deeper waters $(>1000 \mathrm{~m})$.
Although beaked whale sightings in the Gulf of Mexico are scarce, the species has been sighted in all seasons (Waring et al. 2009). They are widely distributed in the deeper waters of the GoM. The summer beaked whale model for the GoM shows highest probability of suitable habitat in the waters offshore of the shelf break in the central and western part of the model area. As shown in the GAM plot, depth was the only variable that produced a response, predicting suitable habitat in deeper waters.

\section{East}

A total of $258693.1 \mathrm{~km}$ (341.4 d) of effort data were available for model building in the US Atlantic EEZ outside the Gulf of Mexico. Aerial surveys comprised $50575.8 \mathrm{~km}$ (218.2 d) of effort, whereas $208117.3 \mathrm{~km}$ (123.2 d) came from ship-based surveys. Habitat suit- 
ability was calculated for 11 guilds in these Atlantic east coast waters: baleen whale, humpback whale, right whale, beaked whale, sperm whale, pilot whale, Lagenorhynchus spp., common dolphin, striped dolphin, bottlenose dolphin, and harbor porpoise. Two guilds, bottlenose dolphin and harbor porpoise, were modeled separately in the smaller regions of East (NE and SE) because of the local intensity of sighting data (Torres et al. 2005). Bottlenose dolphin was modeled in the NE and SE, while harbor porpoise was only modeled in the NE.

The East region represents the US east coast waters out to the EEZ. A further subdivision at Cape Hatteras differentiates between NE and SE. Models were selected for either the broader East or for NE and SE based on ability for the model to converge, variance explained, and a review of expert opinions in the literature.

The North Atlantic right whale Eubalaena glacialis occurs in the Gulf of Maine year round but is observed in large aggregations during spring and summer (Winn et al. 1986, Baumgartner \& Mate 2005, Cole et al. 2007). The modeled summer habitat is consistent with decades of summer right whale sightings in the Gulf of Maine. Further, the GAM plots for the model demonstrate a strong response to depth and SST, which is consistent with the whale's well documented, discrete foraging grounds (Baumgartner et al. 2003).

In the East, beaked whales are observed primarily offshore, along the continental shelf break (Waring et al. 2001, Macleod et al. 2006, Palka 2006). This distribution is reflected in the summer GAM results which confirm a strong association with deep water habitat. The Highest probability of occurrence is just east of the shelf break, which corresponds well with the limited sighting data available for this deep foraging species.

\section{Northeast (NE)}

The distribution of harbor porpoises in the Gulf of Maine is well documented, especially during the summer months. In summer, harbor porpoises occur in the northern reaches of the Gulf of Maine in waters less than $150 \mathrm{~m}$ deep (Gaskin 1977, Kraus et al. 1983, Palka 1995). The species proximity to shore and preference for shallow depths is reflected in the GAM plots for the summer habitat model.

There are 2 genetically distinct morphotypes of bottlenose dolphin Tursiops truncatus in US east coast waters (Duffield et al. 1983): offshore and coastal forms. The offshore form is generally distributed along the outer continental shelf, while the coastal form is continuously distributed along the US east coast from Florida to south of Long Island, New York (Waring et al. 2009). The spring bottlenose dolphin models in the NE represent suitable habitat for the coastal form only, as offshore data were not available for this guild. The GAM plots show a positive response to shallow waters and mid-latitudes.

\section{Southeast (SE)}

In the SE, the spring bottlenose dolphin model reflects habitat preference for the coastal form, as offshore data were not available for this guild. The GAM plots show a positive response to shallow waters. There is also a small positive response to SST between approximately 16 and $21^{\circ} \mathrm{C}$.

\section{DISCUSSION}

We constructed habitat suitability models for 16 guilds of marine mammals in the GoM (9 models) and US east coast (9 models in the East, 2 in the NE, 1 in the SE) regions during seasons (18 in summer, 7 in fall, 3 in winter, 5 in spring) with sufficient data (Table 3). We believe these models will allow planning parties to assess the probability of occurrence for these marine mammal species over specific areas of future planning interest. For instance, the US governmental Bureau of Ocean Energy Management, Regulation and Enforcement (BOEMRE) can use this information for assessing environmental impacts of siting an offshore renewable wind farm. Navy planners can determine appropriate places for ship shock trials which minimize impacts on endangered marine mammals.

After evaluating a variety of modeling approaches independently, we concur with Barlow et al. (2009, p. 92) that GAMs 'offer a robust framework for predictive modeling of cetacean density, as long as sufficient sightings of each species are available and the surveys adequately characterize the full range of oceanographic variability.' Emerging alternative species distribution modeling techniques, such as Maxent, boosted regression trees, random forests, and hierarchical Bayes, may increase predictive accuracy in the future (Elith \& Leathwick 2009). Our models were constrained seasonally and geographically so as to be considered interpolations to unsampled but similar habitats, versus extrapolations to 
novel geographies and/or climates (Elith \& Leathwick 2009). Remotely sensed environmental data, such as SST, can be used effectively to predict the distribution and density of marine mammals at sea. As more marine mammal survey data become available to model with more recent remotely sensed imagery products, such as primary productivity and eddy kinetic energy, improvements should be made towards predictive accuracy and ecological inference of the underlying habitat drivers for species distributions.

Ideally, survey effort expended by multiple platforms will be applied within a full density modeling framework, not just predicting the probability of occurrence. The GAM weighting scheme used here to incorporate effort from ship and aerial surveys is a compromise of publicly available data and accessible modeling techniques for rapidly assessing the probability of occurrence. We are presently working on the full density modeling approach with a more complete dataset integrating different detection probabilities across platforms within a single predictive model fitting procedure.

Our incorporation of geospatial web services to gather the marine mammal datasets and remotelysensed environmental imagery enabled a standardized, automated approach. Since data were extracted through the OBIS-SEAMAP database, the underlying datasets are publicly available and well documented in accordance with the US Federal Geographic Data Committee standards, and extended with the Biological Profile to provide the text-searchable full taxonomic hierarchy fo all sighted species. These analyses are therefore repeatable and updatable as new data become integrated into OBISSEAMAP. The technical details and open philosophy of these metadata standards and data exchange across portals are discussed at length elsewhere (Halpin et al. 2006, 2009, Best et al. 2007, Kot et al. 2010). In the future we hope to extend our modeling and delivery system to forecast cetacean habitats based on oceanographic model predictions.

Lack of data in certain seasons and regions severely limited construction of models for many marine mammal guilds. Such data gaps constrain the predictability of habitats, so should inform planning of future survey activities to fill in data on species environment associations in missing regions and times of the year (Kot et al. 2010). Cetacean research has been given much attention in the Gulf of Maine and Gulf of Mexico in comparison with the area south of Cape Hatteras. Accordingly, differentiation of cetacean habitats could improve greatly with more surveys in the southeastern USA. In addition, we stress the need for more data collection outside of summer, which is the most commonly observed season because of preferred sighting conditions. In some cases, traditional line transect surveys can be conducted in other seasons to address this need. In other situations, it will be necessary to develop alternative methods of inferring species distributions using passive acoustic monitoring and other means. This will be a major challenge for our field in the coming decades.

Recent reviews of species distribution modeling in marine systems (Dambach \& Rödder 2011, Robinson et al. 2011) have highlighted the need to move beyond statistical associations and explicitly model ecological factors such as species interactions, physiological limits, and place-specific behavior (e.g. feeding, breeding, and migrating). This work provides a valuable baseline for improving upon these correlative models with additional process-based complexity in the future.

Our SDSS hosts the results of our modeling results, together with density model outputs from the Pacific (Barlow et al. 2009) and the NODE model outputs of spatial variation in marine mammal density in the Atlantic. These products are publicly available on the web in an interactive format that allows users to download model outputs, view input data, examine model diagnostics, and query data sets. This SDSS is especially relevant to any activities in which planning, permitting, assessing, or monitoring is related to the distribution of cetaceans.

Together with our colleagues from the Southwest Fisheries Science Center, we identified a variety of potential users: US Navy, Air Force, Coast Guard, Army Corps of Engineers, Minerals Management Service, National Science Foundation, National Marine Fisheries Service Science Centers and Regional Offices, universities, and oil exploration companies. Military exercises require environmental impact assessment in relation to cetaceans (Dolman et al. 2009). Facilities for offshore renewable energies, such as wind and wave, pose another modern potential impact on cetaceans (Dolman \& Simmonds 2010). Human use and impacts on the ocean continue to be on the rise, to which systematic planning under the auspices of 'ocean zoning' (Crowder et al. 2006, Halpern et al. 2008) or 'marine spatial planning' (Douvere 2008) by the USA (Lubchenco \& Sutley 2010) and internationally (Ardron et al. 2008, Ehler \& Douvere 2009) has been hailed as a comprehensive management solution. In order to best plan for such activities, there will be a continuing need to improve our models of the density and distribution of endangered species and to deliver model outputs online as real-time forecasts. 
Acknowledgements. Funding for this project was provided by the Strategic Environmental Research and Development Program (SERDP) under Conservation Project CS-1390, and by NASA's Ecological Forecasting program under cooperative grant NNX08AK73G. Dedicated research teams at NOAA's Northeast and Southeast Fisheries Science Centers (NEFSC and SEFSC) and the University of North Carolina Wilmington (UNCW data collected under NOAA Research Permit no. 1031 and 948-1692-00 to UNCW and under NEAq and NOAA SER permits) collected much of the marine mammal survey data used in the development of our models. We thank all of the researchers, marine mammal observers, survey coordinators, ship crews, and officers who have worked hard over the past $20 \mathrm{yr}$ to collect the data that we used here. Without their efforts, none of our work would have been possible. In particular, we thank K. Mullen for providing access to the SEFSC data. We are also grateful to J. Bell, D. Rees, K. Jenkins, A. Kumar, C. Watterson, M. Shoemaker, J. Rivers, and their colleagues for their insight into the requirements of the Navy environmental planning community. F. Stone, E. Young, and B. Gisiner provided critical support throughout the course of the project. W. Turner has been very supportive of an improved SDSS and ecological forecasting through NASA. Our project benefitted greatly from our close collaboration with our sister project at the Southwest Fisheries Science Center (SWFSC; SI-1391). We thank our colleagues from the SWFSC, J. Barlow, M. Ferguson, J. Redfern, E. Becker, and K. Forney, for their assistance and thoughtful insights. We are also thankful for the assistance and cooperation of colleagues from Geo-Marine, Inc. S. Freeman and D. Hyrenbach were instrumental in the genesis and early development of this work. Manuscript comments provided by the editor E. Gregr, anonymous reviewers and F. Huettmann greatly improved the manuscript. Finally, we thank J. Hall and the rest of the SERDP staff for their steady support throughout the life of this project.

\section{LITERATURE CITED}

Aguilar A, Borrell A, Reijnders PJH (2002) Geographical and temporal variation in levels of organochlorine contaminants in marine mammals. Mar Environ Res 53: 425-452

Alter ES, Simmonds MP, Brandon JR (2010) Forecasting the consequences of climate-driven shifts in human behavior on cetaceans. Mar Policy 34:943-954

Angel MV (1979) Zoogeography of the Atlantic ocean. In: van der Spoel S, Pierrot-Bults AC (eds) Zoogeography and diversity of plankton. Edward Arnold, London, p 144-167

Ardron J, Gjerde K, Pullen S, Tilot V (2008) Marine spatial planning in the high seas. Mar Policy 32:832-839

Austin M (2007) Species distribution models and ecological theory: a critical assessment and some possible new approaches. Ecol Modell 200:1-19

Barlow J, Ferguson MC, Becker EA, Redfern JV and others (2009) Predictive modeling of cetacean densities in the Eastern Pacific Ocean. US Department of Commerce, NOAA Tech Mem NMFS, NOAA-TM-NMFS-SWFSC444

Baumgartner MF, Mate BR (2005) Summer and fall habitat of North Atlantic right whales (Eubalaena glacialis) inferred from satellite telemetry. Can J Fish Aquat Sci 62: $527-543$
Baumgartner MF, Mullin KD, May LN, Leming TD (2001) Cetacean habitats in the northern Gulf of Mexico. Fish Bull 99:219-239

- Baumgartner MF, Cole TVN, Clapham PJ, Mate BR (2003) North Atlantic right whale habitat in the lower Bay of Fundy and on the SW Scotian Shelf during 1999-2001. Mar Ecol Prog Ser 264:137-154

> Best BD, Halpin PN, Fujioka E, Read AJ, Qian SS, Hazen LJ, Schick RS (2007) Geospatial web services within a scientific workflow: predicting marine mammal habitats in a dynamic environment. Ecol Inform 2:210-223

Buckland ST, Anderson DR, Burnham KP, Laake JL, Borchers DL, Thomas L (2001) Introduction to distance sampling. Oxford University Press, New York, NY

Cole TVN, Gerrior P, Merrick RL (2007) Methodologies of the NOAA National Marine Fisheries Service aerial survey program for right whales (Eubalaena glacialis) in the Northeast US, 1998-2006. Ref Doc:07-02. US Department of Commerce, Northeast Fisheries Science Center, Woods Hole, MA

Crowder LB, Osherenko G, Young OR, Airame S and others (2006) Sustainability: resolving mismatches in U.S. ocean governance. Science 313:617-618

Cushman SA, Huettmann F (eds) (2010) Spatial complexity, informatics, and wildlife conservation. Springer, Tokyo

Dambach J, Rödder D (2011) Applications and future challenges in marine species distribution modeling. Aquat Conserv 21:92-100

> Davis RW, Fargion GS, May N, Leming TD and others (1998) Physical habitat of cetaceans along the continental slope in the northcentral and western Gulf of Mexico. Mar Mamm Sci 14:490-507

> Dolman S, Simmonds M (2010) Towards best environmental practice for cetacean conservation in developing Scotland's marine renewable energy. Mar Policy 34:1021-1027

> Dolman SJ, Weir CR, Jasny M (2009) Comparative review of marine mammal guidance implemented during naval exercises. Mar Pollut Bull 58:465-477

DON (Department of the Navy) (2007a) Navy OPAREA Density Estimates (NODE) for the GOMEX OPAREA. Naval Facilities Engineering Command, Atlantic; Norfolk, VA. Contract N62470-02-D-9997, Task Order 0046. Prepared by Geo-Marine, Hampton, VA

DON (Department of the Navy) (2007b) Navy OPAREA Density Estimates (NODE) for the Northeast OPAREAS: Boston, Narragansett Bay, and Atlantic City. Naval Facilities Engineering Command, Atlantic; Norfolk, Virginia. Contract N62470-02-D-9997, Task Order 0045. Prepared by Geo-Marine, Plano, TX

DON (Department of the Navy) (2007c). Navy OPAREA Density Estimates (NODE) for the Southeast OPAREAS: VACAPES, CHPT, JAXICHASN, and Southeastern Florida \& AUTEC-Andros. Naval Facilities Engineering Command, Atlantic; Norfolk, VA. Contract N62470-02D-9997, Task Order 0060. Prepared by Geo-Marine, Hampton, VA

Douvere F (2008) The importance of marine spatial planning in advancing ecosystem-based sea use management. Mar Policy 32:762-771

> Duffield DA, Ridgway SH, Cornell LH (1983) Hematology distinguishes coastal and offshore forms of dolphins (Tursiops). Can J Zool 61:930-933

Ehler C, Douvere F (2009) Marine spatial planning. A stepby-step approach toward ecosystem-based management. Intergovernmental Oceanographic Commission 
and Man and the Biosphere Programme. IOC Manuals and Guides No. 53, ICAM Dossier No. 6. UNESCO, Paris

Ekman S (1953) Zoogeography of the sea. Sidgwick and Jackson, London

Elith J, Leathwick JR (2009) Species distribution models: ecological explanation and prediction across space and time. Annu Rev Ecol Evol Syst 40:677-697

Fielding AH, Bell JF (1997) A review of methods for the assessment of prediction errors in conservation presence/absence models. Environ Cons 24:38-49

Fonnesbeck CJ, Garrison LP, Ward-Geiger LI, Baumstark RD (2008) Bayesian hierarchical model for evaluating the risk of vessel strikes on North Atlantic right whales in the SE United States. Endang Species Res 6:87-94

Forney KA, Ferguson MC, Becker EA, Fiedler PC and others (2012) Habitat-based spatial models of cetacean density in the eastern Pacific Ocean. Endang Species Res 16: 113-133

Franklin J, Miller JA (2010) Mapping species distributions: spatial inference and prediction. Cambridge University Press, Cambridge

Fulling GL, Mullin KD, Hubard CW (2003) Abundance and distribution of cetaceans in outer continental shelf waters of the U. S. Gulf of Mexico. Fish Bull 101:923-932

Gaskin DE (1977) Harbour porpoise, Phocoena phocoena (L.), in the western approaches to the Bay of Fundy 1969-75. Rep Int Whal Comm 27:487-492

> Guisan A, Zimmermann NE (2000) Predictive habitat distribution models in ecology. Ecol Model 135:147-186

> Halpern BS, McLeod KL, Rosenberg AA, Crowder LB (2008) Managing for cumulative impacts in ecosystem-based management through ocean zoning. Ocean Coast Manag 51:203-211

Halpin PN, Read AJ, Best BD, Hyrenbach KD and others (2006) OBIS-SEAMAP: developing a biogeographic research data commons for the ecological studies of marine mammals, seabirds, and sea turtles. Mar Ecol Prog Ser 316:239-246

Halpin PN, Read AJ, Fujioka E, Best BD and others (2009) OBIS-SEAMAP: the world data center for marine mammal, sea bird, and sea turtle distributions. Oceanography 22:104-115

Hamazaki T (2002) Spatiotemporal prediction models of cetacean habitats in the mid-western North Atlantic Ocean (from Cape Hatteras, North Carolina, U.S.A. to Nova Scotia, Canada). Mar Mamm Sci 18:920-939

Hansen LJ, Mullin KD, Jefferson TA, Scott GP (1996) Visual surveys aboard ships and aircraft. In: Davis RW, Fargion GS (eds) Distribution and abundance of cetaceans in the north-central and western Gulf of Mexico: final report II, Vol II technical report. OCS Study MMS 96-0027. US Department of the Interior, Minerals Management Service, Gulf of Mexico OCS Region, New Orleans, LA, p 55-132

Hutchinson GE (1957) Concluding remarks. Cold Spring Harbor Symp Quant Biol 22:415-427

Jochens AE, Biggs DC (2003) Sperm whale seismic study in the Gulf of Mexico, Annual Report: Year 1. OCS Study MMS 69. US Department of the Interior, Minerals Management Service, Gulf of Mexico OCS Region, New Orleans, LA

Kilpatrick KA, Podestá GP, Evans R (2001) Overview of the NOAA/NASA advanced very high resolution radiometer Pathfinder algorithm for sea surface temperature and associated matchup database. J Geophys Res 106: 9179-9197
Kot CY, Fujioka E, Hazen LJ, Best BD, Read AJ, Halpin PN (2010) Spatio-temporal gap analysis of OBIS-SEAMAP project data: assessment and way forward. PLoS ONE 5: e12990

Kraus SD, Prescott JH, Stone GS (1983) Harbor porpoise, Phocoena phocoena, in the US coastal waters of the Gulf of Maine: a survey to determine seasonal distribution and abundance. Report NMFS NA82FAC00027 to the Director, National Marine Fisheries Service, Northeast Region, Woods Hole, MA

Laist DW, Knowlton AR, Mead JG, Collet AS, Podesta M (2001) Collisions between ships and whales. Mar Mamm Sci 17:35-75

Learmonth J, Macleod C, Santos M, Pierce GJ, Crick HQP, Robinson RA (2006) Potential effects of climate change on marine mammals. Oceanogr Mar Biol Annu Rev 44: 431-464

> Lubchenco J, Sutley N (2010) Proposed U.S. policy for ocean, coast, and Great Lakes stewardship. Science 328: 1485-1486

Macleod CD (2000) Review of the distribution of Mesoplodon species (order Cetacea, family Ziphiidae) in the North Atlantic. Mammal Rev 30:1-8

Macleod CD, Perrin WF, Pitman R, Barlow J and others (2006) Known and inferred distributions of beaked whale species (Cetacea: Ziphiidae). J Cetacean Res Manag 7: 271-286

> Moore JE, Wallace BP, Lewison RL, Zydelis R, Cox TM, Crowder LB (2009) A review of marine mammal, sea turtle and seabird bycatch in USA fisheries and the role of policy in shaping management. Mar Policy 33:435-451

Mullin KD, Fulling GL (2004) Abundance of cetaceans in the oceanic northern Gulf of Mexico, 1996-2001. Mar Mamm Sci 20:787-807

Mullin KD, Hoggard W (2000) Visual surveys of cetaceans and sea turtles from aircraft and ships. In: Davis RW, Evans WE, Würsig B (eds) Cetaceans, sea turtles and seabirds in the northern Gulf of Mexico: distribution, abundance and habitat associations. Vol II Tech Rep. OCS Study MMS 96-0027. USGS/BRD/CR-1999-0006. Minerals Management Service, Gulf of Mexico OCS Region, New Orleans, LA, p 111-172

O'Shea TJ, Brownell RL Jr (1994) Organochlorine and metal contaminants in baleen whales: a review and evaluation of conservation implications. Sci Total Environ 154: 179-200

Palka DL (1995) Influences on spatial patterns of Gulf of Maine harbor porpoises. Dev Mar Biol 4:69-75

Palka DL (2006) Summer abundance estimates of cetaceans in US North Atlantic Navy Operating Areas. US Department of Commerce Northeast Fish Sci Cent Ref Doc: 06-03. National Marine Fisheries Service, Woods Hole, MA

Pershing AJ, Record NR, Monger BC, Mayo CA and others (2009) Model-based estimates of right whale habitat use in the Gulf of Maine. Mar Ecol Prog Ser 378:245-257

Phillips SJ, Dudik M (2008) Modeling of species distributions with Maxent: new extensions and a comprehensive evaluation. Ecography 31:161-175

> Phillips SJ, Dudík M, Elith J, Graham CH, Lehmann A, Leathwick J, Ferrier S (2009) Sample selection bias and presence-only distribution models: implications for background and pseudo-absence data. Ecol Appl 19:181-197

Pittman SJ, Costa B (2010) Linking cetaceans to their environment: spatial data acquisition, digital processing and 
predictive modeling for marine spatial planning in the Northwest Atlantic. In: Cushman SA, Huettmann F (eds) Spatial complexity, informatics, and wildlife conservation. Springer, Tokyo, p 387-408

Pittman S, Costa B, Kot C, Wiley D, Kenney RD (2006) Cetacean distribution and diversity. In: Battista T, Clark R, Pittman S (eds) An ecological characterization of the Stellwagen Bank National Marine Sanctuary region: oceanographic, biogeographic, and contaminants assessment. NOAA Tech Memo NOS NCCOS 45. NOAA National Centers for Coastal Ocean Science, Silver Spring, MD, p 265-326

R Development Core Team (2008) R: a language and environment for statistical computing. R Foundation for Statistical Computing, Vienna

Read AJ (2008) The looming crisis: interactions between marine mammals and fisheries. J Mammal 89:541-548

Ready J, Kaschner K, South AB, Eastwood PD and others (2010) Predicting the distributions of marine organisms at the global scale. Ecol Model 221:467-478

Redfern JV, Ferguson MC, Becker EA, Hyrenbach KD and others (2006) Techniques for cetacean-habitat modeling. Mar Ecol Prog Ser 310:271-295

Reilly S, Fiedler P (1994) Interannual variability of dolphin habitats in the eastern tropical Pacific. I: Research vessel surveys, 1986-1990. Fish Bull 92:434-450

Roberts JJ, Best BD, Dunn DC, Treml EA, Halpin PN (2010) Marine geospatial ecology tools: an integrated framework for ecological geoprocessing with ArcGIS, Python, R, MATLAB, and C++. Environ Model Softw 25:1197-1207

Robinson LM, Elith J, Hobday AJ, Pearson RG, Kendall BE, Possingham HP, Richardson AJ (2011) Pushing the limits in marine species distribution modelling: lessons from the land present challenges and opportunities. Glob Ecol Biogeogr 20:789-802

Schick RS, Halpin PN, Read AJ, Urban DL and others (2011) Community structure in pelagic marine mammals at large spatial scales. Mar Ecol Prog Ser 434:165-181

Editorial responsibility: Edward Gregr,

Vancouver, British Columbia, Canada
Tetley MJ, Mitchelson-Jacob EG, Robinson KP (2008) The summer distribution of coastal minke whales (Balaenoptera acutorostrata) in the southern outer Moray Firth, NE Scotland, in relation to co-occurring mesoscale oceanographic features. Remote Sens Environ 112: 3449-3454

> Thomas L, Buckland ST, Rexstad EA, Laake JL and others (2010) Distance software: design and analysis of distance sampling surveys for estimating population size. J Appl Ecol 47:5-14

Torres LG, Mclellan WA, Meagher E, Pabst D (2005) Seasonal distribution and relative abundance of bottlenose dolphins, Tursiops truncatus, along the US mid-Atlantic coast. J Cetacean Res Manag 7:153-161

> Waring GT, Hamazaki T, Sheehan D, Wood G, Baker S (2001) Characterization of beaked whale (Ziphiidae) and sperm whale (Physeter macrocephalus) summer habitat in shelf-edge and deeper waters off the Northeast US. Mar Mamm Sci 17:703-717

Waring GT, Josephson E, Fairfield-Walsh CP, Maze-Foley K (eds) (2009) US Atlantic and Gulf of Mexico marine mammal stock assessments-2008. NOAA Tech Memo NMFS NE 210. Northeast Fisheries Science Center, Woods Hole, MA

Weilgart LS (2007) The impacts of anthropogenic ocean noise on cetaceans and implications for management. Can J Zool 85:1091-1116

Wessel P, Smith WHF (1996) A global, self-consistent, hierarchical, high-resolution shoreline database. J Geophys Res 101:8741-8743

Winn HE, Price CA, Sorensen PW (1986) The distributional biology of the right whale (Eubalaena glacialis) in the western North Atlantic. In: Brownell RL, Best PB, Prescott JH (eds) Right whales: past and present status: proceedings of the Workshop on the Status of Right Whales, New England Aquarium, Boston, MA, 15-23 June 1983. International Whaling Commission, Cambridge, p 129-138

Wood SN (2006) Generalized additive models: an introduction with R. CRC Press, Boca Raton, FL

Submitted: January 16, 2011; Accepted: March 5, 2012 Proofs received from author(s): June 25, 2012 